
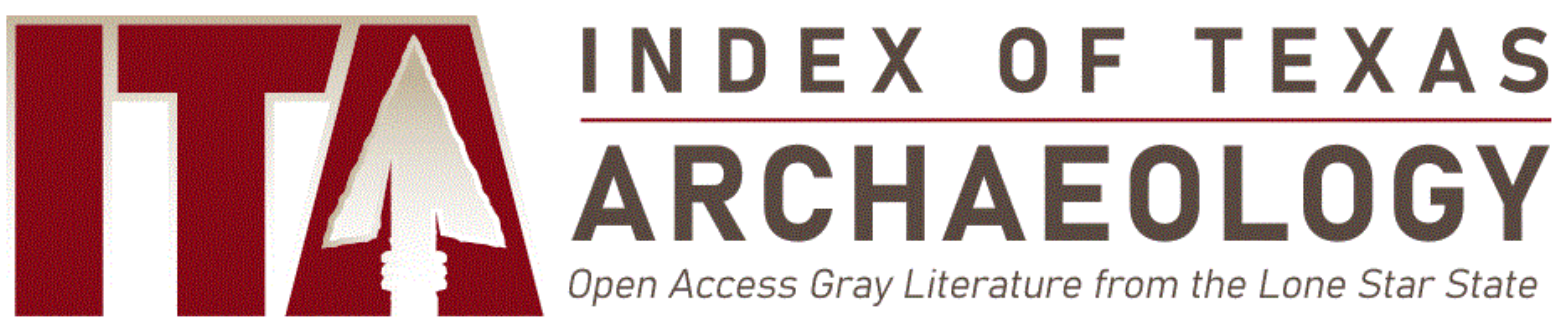

Open Access Gray Literature from the Lone Star State

Volume 2017

Article 1

2017

\title{
Renewed Archaeological Investigations at the Bowles Creek (41CE475), Cornfield (41CE476), and Peach Orchard (41CE477) Sites in the Bowles Creek Valley, Cherokee County, Texas
}

Timothy K. Perttula

Heritage Research Center, Stephen F. Austin State University

Kevin Stingley

Texas Archeological Stewardship Network, Texas Historical Commission

Follow this and additional works at: https://scholarworks.sfasu.edu/ita

Part of the American Material Culture Commons, Archaeological Anthropology Commons, Environmental Studies Commons, Other American Studies Commons, Other Arts and Humanities Commons, Other History of Art, Architecture, and Archaeology Commons, and the United States History Commons

Tell us how this article helped you.

This Article is brought to you for free and open access by the Center for Regional Heritage Research at SFA ScholarWorks. It has been accepted for inclusion in Index of Texas Archaeology: Open Access Gray Literature from the Lone Star State by an authorized editor of SFA ScholarWorks. For more information, please contact cdsscholarworks@sfasu.edu. 
Renewed Archaeological Investigations at the Bowles Creek (41CE475), Cornfield (41CE476), and Peach Orchard (41CE477) Sites in the Bowles Creek Valley, Cherokee County, Texas

Creative Commons License

(c) (1) (9)

This work is licensed under a Creative Commons Attribution-NonCommercial 4.0 International License 


\title{
Renewed Archaeological Investigations at the Bowles Creek (41CE475), Cornfield (41CE476), and Peach Orchard (41CE477) Sites in the Bowles Creek Valley, Cherokee County, Texas
}

\author{
Timothy K. Perttula and Kevin Stingley
}

\section{Introduction and Summary of Previous Investigations}

There are a number of Allen phase Historic Caddo sites on Bowles Creek (Figure 1), a southwardflowing tributary to the Neches River in the East Texas Pineywoods, including the Bowles Creek (41CE475), Cornfield (41CE476), and Peach Orchard (41CE477) sites (Perttula and Stingley 2016a, 2016b; Perttula et al. 2016). In conjunction with remote sensing investigations conducted by Dr. Duncan P. McKinnon (University of Central Arkansas), renewed archaeological investigations have been completed in January 2016 at these three sites to better understand the subsurface character of their archaeological deposits.

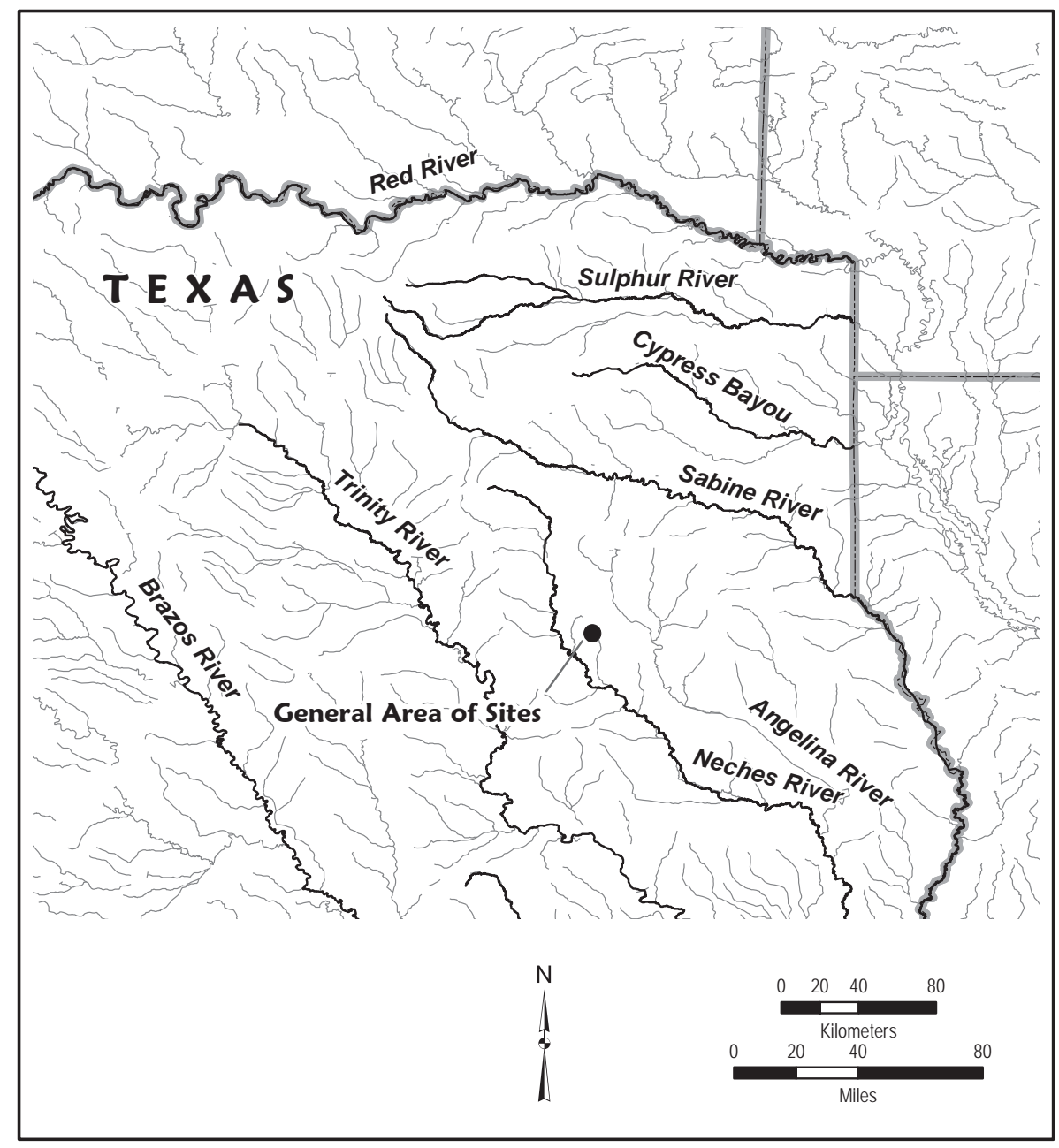

Figure 1. General location of the Bowles Creek Caddo sites in East Texas. 
At the Bowles Creek site, on a low alluvial rise, the first investigations included a surface collection, along with the excavation of a number of shovel tests $(\mathrm{n}=13$, generally $35-40 \times 55-60 \mathrm{~cm}$ in width and length and 30-50 cm in depth) as well as three units (Units $1-3$, generally $1 \times 1 \mathrm{~m}$ in size) done by Stingley at the site; the units were excavated to between $50-80 \mathrm{~cm}$ bs (Perttula et al. 2016). These initial archaeological investigations at the Bowles Creek site recovered 617 ceramic sherds (Perttula et al. 2016:Table 13), of which 461 were decorated. A single radiocarbon date has been obtained on a piece of animal bone from Unit 3, 40-50 cm bs, at the site. The radiocarbon age of this AMS sample from the Bowles Creek site is $410 \pm 24$ years B.P. (D-AMS 11799), or A.D. $1540 \pm 24$. The 2 sigma calibration (95 percent probability) of this radiocarbon age, using IntCal13 (Reimer et al. 2013), is A.D. $1525 \pm 84$. This result suggests that there are also Frankston phase (ca. A.D. 1400-1650) archaeological deposits preserved at the site.

An additional sample of material culture remains from the Bowles Creek site was obtained by Stingley in July and August 2015, primarily from areas recently disturbed by wild hogs (see Perttula and Stingley 2016:Figure 2). This surface collection recovered another 337 ceramic sherds, including 206 decorated sherds (Perttula and Stingley 2016a:Table 1). There were also a small number of unburned animal bones and teeth in this surface collection, as well as a gray novaculite Cuney arrow point.

The Cornfield site is on an upland ridge between Bowles Creek and Turkey Creek, and is known as the 1870s cornfield of an Anglo-American settler on this tract of land. In the only archaeological work at the site before the investigations reported on herein, a 2 acre area of the landform was recently plowed and disked, and archaeological evidence of a Caddo settlement was obtained from a surface collection (Perttula et al. 2016). The surface collection had 227 ceramic vessel sherds, including 156 decorated sherds (Perttula et al. 2016:Table 5).

The first work at the Peach Orchard site consisted of a general surface collection from the grasscovered upland landform (Perttula et al. 2016). That work recovered 71 ceramic sherds, 60 of which were decorated (Perttula et al. 2016:Table 9). In November 2015, the landowner decided to shallowly plow the site area to improve its grass cover, and this plowing provided an opportunity to complete a comprehensive surface collection of the site area from November to December 2015. After the site area and the larger field had been plowed and rained on several times, a grid of $2110 \times 10 \mathrm{~m}$ units (numbered 1-21) was laid out over the known surface spatial distribution of ancestral Caddo ceramic sherds (Perttula and Stingley 2016b:Figures 2 and 3).

The systematic surface collection recovered 2102 ceramic vessel sherds, 1496 of which were decorated, two ceramic elbow pipe sherds, a clay coil, two burned clay pieces, 12 chipped stone tools (including two dart points from a Woodland period component), 67 pieces of lithic debris, one core, one firecracked rock, four animal bones, and 14 mid-nineteenth to early $20^{\text {th }}$ century historic artifacts (Perttula and Stingley 2016b). Based on the distribution of the major categories (i.e., total sherds, and the distributions of utility ware and fine ware sherds) of ancestral Caddo artifacts across the site, the core area with the highest density of all categories of Caddo artifacts is in a 700 square meter area in the central and eastern part of the surface collection grid (Perttula and Stingley 2016b:Figure 4).

\section{Bowles Creek Site (41CE475)}

Additional shovel tests $(n=14)$ were excavated at the Bowles Creek site in January 2016, most in the northern part of the landform, but two shovel tests were also excavated near the artificial cut of the Bowles Creek channel (Figure 2), and one other shovel test was placed between the channel cut bank and the remainder of the shovel tests. All but one shovel test contained ancestral Caddo artifacts in a reddishbrown sandy loam deposit (Table 1). The sandy loam sediments ranged from 40-100+ $\mathrm{cm}$ in thickness, and where the clay B-horizon was encountered, it was a red clay. The sandy loam deposits increase in thickness from north to south towards the creek channel. 


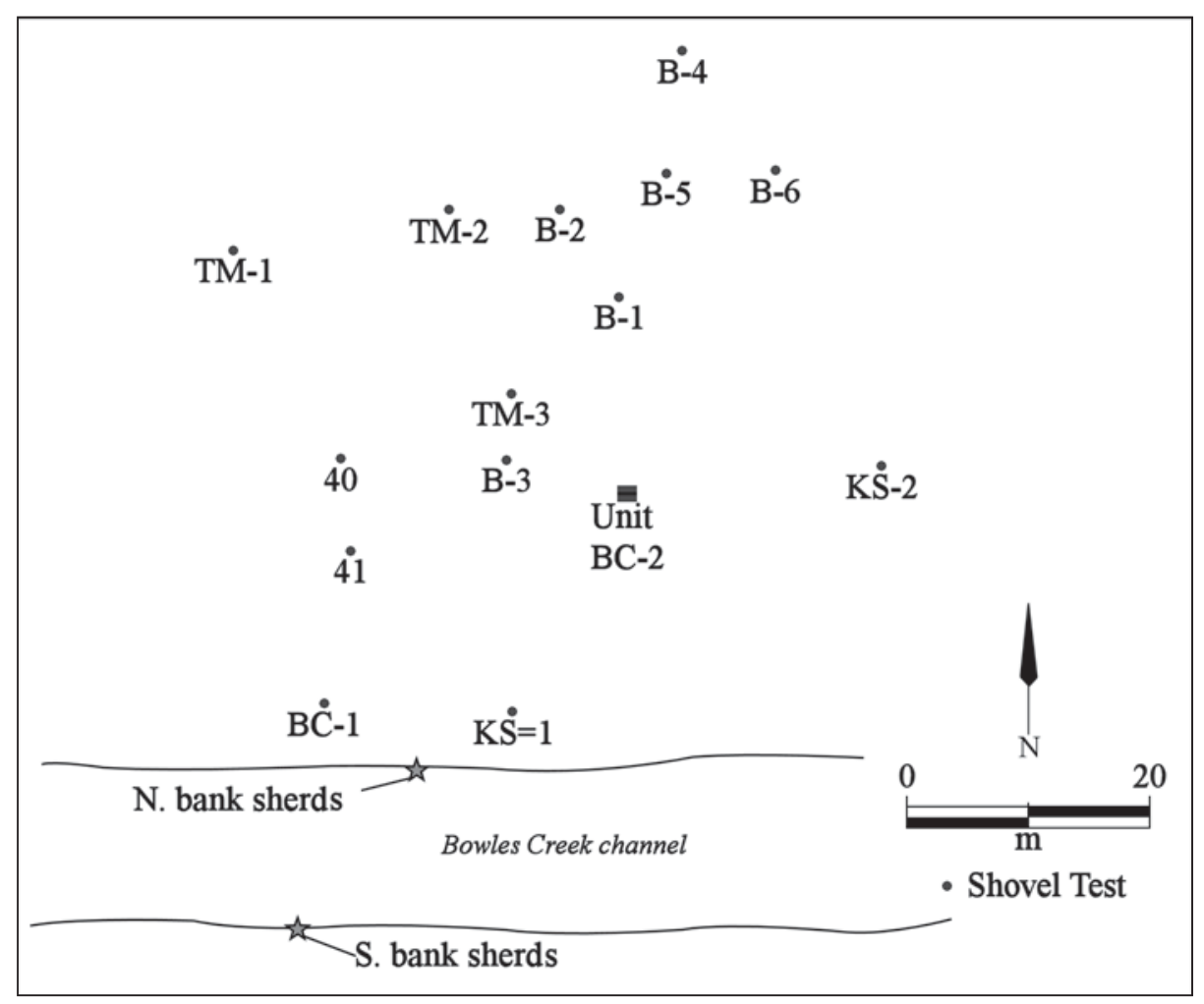

Figure 2. Map of the location of shovel tests at the Bowles Creek site, and Unit BC-2.

Table 1. Descriptions of positive shovel tests at the Bowles Creek site.

\begin{tabular}{|c|c|c|}
\hline ST Number & Description & Artifacts \\
\hline B-1 & $0-100 \mathrm{~cm}+$, reddish-brown sandy loam & $\begin{array}{l}\text { ceramic sherds, } 0-40 \\
\mathrm{~cm} \text { bs; lithic debris, } \\
20-40 \mathrm{~cm} \text { bs }\end{array}$ \\
\hline B-2 & $0-100 \mathrm{~cm}+$, reddish-brown sandy loam & $\begin{array}{l}\text { ceramic sherds, } 0-40 \\
\mathrm{~cm} \text { bs; lithic debris, } \\
0-20 \mathrm{~cm} \text { bs }\end{array}$ \\
\hline B-3 & $\begin{array}{l}0-74 \mathrm{~cm} \text {, reddish-brown sandy loam; } \\
74-76 \mathrm{~cm}+\text {, red clay }\end{array}$ & $\begin{array}{l}\text { ceramic sherds, } 0-60 \\
\mathrm{~cm} \text { bs }\end{array}$ \\
\hline B-4 & $\begin{array}{l}0-41 \mathrm{~cm}, \text { reddish-brown sandy loam; } \\
41-43 \mathrm{~cm}+\text {, red clay }\end{array}$ & $\begin{array}{l}\text { ceramic sherds, } 0-40 \\
\mathrm{~cm} \text { bs }\end{array}$ \\
\hline B-5 & $\begin{array}{l}0-40 \mathrm{~cm} \text {, reddish-brown sandy loam; } \\
40-42 \mathrm{~cm}+\text {, red clay }\end{array}$ & $\begin{array}{l}\text { ceramic sherds, } 0-40 \\
\mathrm{~cm} \text { bs }\end{array}$ \\
\hline B-6 & $\begin{array}{l}\text { 0-58 cm, reddish-brown sandy loam; } \\
58-61 \mathrm{~cm}+\text {, red clay }\end{array}$ & $\begin{array}{l}\text { ceramic sherds, } 0-40 \\
\mathrm{~cm} \text { bs; lithic debris, } \\
0-20 \mathrm{~cm} \text { bs }\end{array}$ \\
\hline
\end{tabular}


Table 1. Descriptions of positive shovel tests at the Bowles Creek site, cont.

\begin{tabular}{|c|c|c|}
\hline ST Number & Description & Artifacts \\
\hline BC-1 & $\begin{array}{l}\text { 0-35 cm, yellowish-brown sandy loam; } \\
35-80 \mathrm{~cm}+\text {, dark yellowish-brown sandy } \\
\text { loam with charcoal flecks }\end{array}$ & $\begin{array}{l}\text { ceramic sherds, } 0-20 \\
\mathrm{~cm} \text { bs and } 40-80 \\
\mathrm{~cm} \text { bs }\end{array}$ \\
\hline $\mathrm{KS}-2$ & $0-70 \mathrm{~cm}+$, reddish-brown sandy loam & $\begin{array}{l}\text { ceramic sherds, } 0-40 \\
\mathrm{~cm} \text { bs and } 60-70 \mathrm{~cm} \text { bs }\end{array}$ \\
\hline TM-1 & $\begin{array}{l}0-40 \mathrm{~cm} \text {, reddish-brown sandy loam; } \\
40-55 \mathrm{~cm}+\text {, red clay }\end{array}$ & $\begin{array}{l}\text { ceramic sherds, } 0-40 \\
\mathrm{~cm} \text { bs }\end{array}$ \\
\hline TM-2 & $0-25 \mathrm{~cm}+$, reddish-brown sandy loam & $\begin{array}{l}\text { ceramic sherds, } 0-25 \\
\mathrm{~cm} \text { bs; lithic debris, } \\
0-25 \mathrm{~cm} \text { bs }\end{array}$ \\
\hline TM-3 & $\begin{array}{l}0-60 \mathrm{~cm} \text {, reddish-brown sandy loam; } \\
60-80 \mathrm{~cm}+\text {, dark red clay }\end{array}$ & $\begin{array}{l}\text { ceramic sherds, } 0-60 \\
\mathrm{~cm} \mathrm{bs}\end{array}$ \\
\hline ST 40 & $\begin{array}{l}0-60 \mathrm{~cm} \text {, reddish-brown sandy loam; } \\
60-65 \mathrm{~cm}+\text {, brown sandy loam }\end{array}$ & $\begin{array}{l}\text { ceramic sherds, } 0-65 \\
\text { cm bs }\end{array}$ \\
\hline ST 41 & $\begin{array}{l}0-60 \mathrm{~cm} \text {, reddish-brown sandy loam; } \\
60-65 \mathrm{~cm}+\text {, brown sandy loam }\end{array}$ & $\begin{array}{l}\text { ceramic sherds, } 0-65 \\
\mathrm{~cm} \text { bs }\end{array}$ \\
\hline
\end{tabular}

In addition to these shovel tests, the cut bank of Bowles Creek was examined, and ancestral Caddo ceramic sherds $(n=6)$ were noted buried in the alluvial sediments between $100-140 \mathrm{~cm}$ bs. It is likely that there are buried Caddo archaeological deposits both north and south of the creek channel, and that these deposits trend upwards to merge with the archaeological deposits encountered in the shovel tests on the low alluvial rise. The deposits encountered in Shovel Test BC-1, near the northern cut bank of the channel (see Figure 2), suggest that there is a buried soil between $35-80 \mathrm{~cm}+$ bs with charcoal flecks and Caddo ceramic vessel sherds (see Table 1).

The density of artifacts in the positive shovel tests is 8.7 artifacts per positive shovel test (Table 2), or ca. 69.6 artifacts per square meter of archaeological deposits. The highest densities are in the central and western part of the landform (see Figure 2). Ceramic vessel sherds comprise 95 percent of the recovered artifacts, there is one ceramic elbow pipe sherd from ST 40, and the remaining 4 percent are pieces of lithic debris.

A single 1 x $1 \mathrm{~m}$ unit (Unit BC-2) was excavated in the central part of the rise, adjacent to Unit 3 excavated by Stingley in 2015 (see Perttula et al. 2016:Figure 12). In that unit was a high density of ceramic sherds, as well as animal bone and burned clay pieces at ca. $60 \mathrm{~cm}$ bs that suggested that a cultural feature was encountered in the excavations there. Our purpose in excavating Unit BC-2 was to assess the subsurface character of the archaeological deposits and determine if features were present in this part of the site.

The archaeological deposits in Unit BC-2 are a reddish-brown sandy loam to $50 \mathrm{~cm}$ bs. At $40 \mathrm{~cm}$, the tops of two circular post hole stains of a dark brown sandy loam were identified adjacent to each other in the floor of the unit (Figure 3a). The post holes (Stains 4 and 5) were 21-22 cm in diameter, with charcoal flecks and animal bone. The Stain 4 post hole had straight sides and a rounded bottom and extended to 92 $\mathrm{cm}$ bs (Figure 3b), while Stain 5 extended to $74 \mathrm{~cm}$ bs, and also had straight sides and a rounded bottom. The size of the post holes in the unit suggest that a portion of a Caddo house structure was encountered in the excavations. 
Table 2. Distribution of artifacts from the positive shovel tests at the Bowles Creek site.

\begin{tabular}{lllll}
\hline ST No. & Plain Sherds & Decorated Sherds & Lithic Debris & N \\
\hline B-1 & 1 & 2 & 1 & 4 \\
B-2 & 3 & 2 & 1 & 6 \\
B-3 & 4 & 3 & - & 7 \\
B-4 & - & 2 & - & 2 \\
B-5 & 2 & 3 & - & 5 \\
B-6 & 3 & 4 & 1 & 8 \\
BC-1 & 2 & 4 & - & 6 \\
KS-2 & 1 & 4 & - & 5 \\
TM-1 & 7 & 2 & - & 9 \\
TM-2 & 4 & 4 & - & 9 \\
TM-3 & 3 & 6 & - & 9 \\
ST 40 & 9 & 18 & 1 & $28 *$ \\
ST 41 & 7 & 18 & 5 & 26 \\
\hline Totals & 46 & 72 & & 124 \\
\hline
\end{tabular}

*includes a single elbow pipe sherd

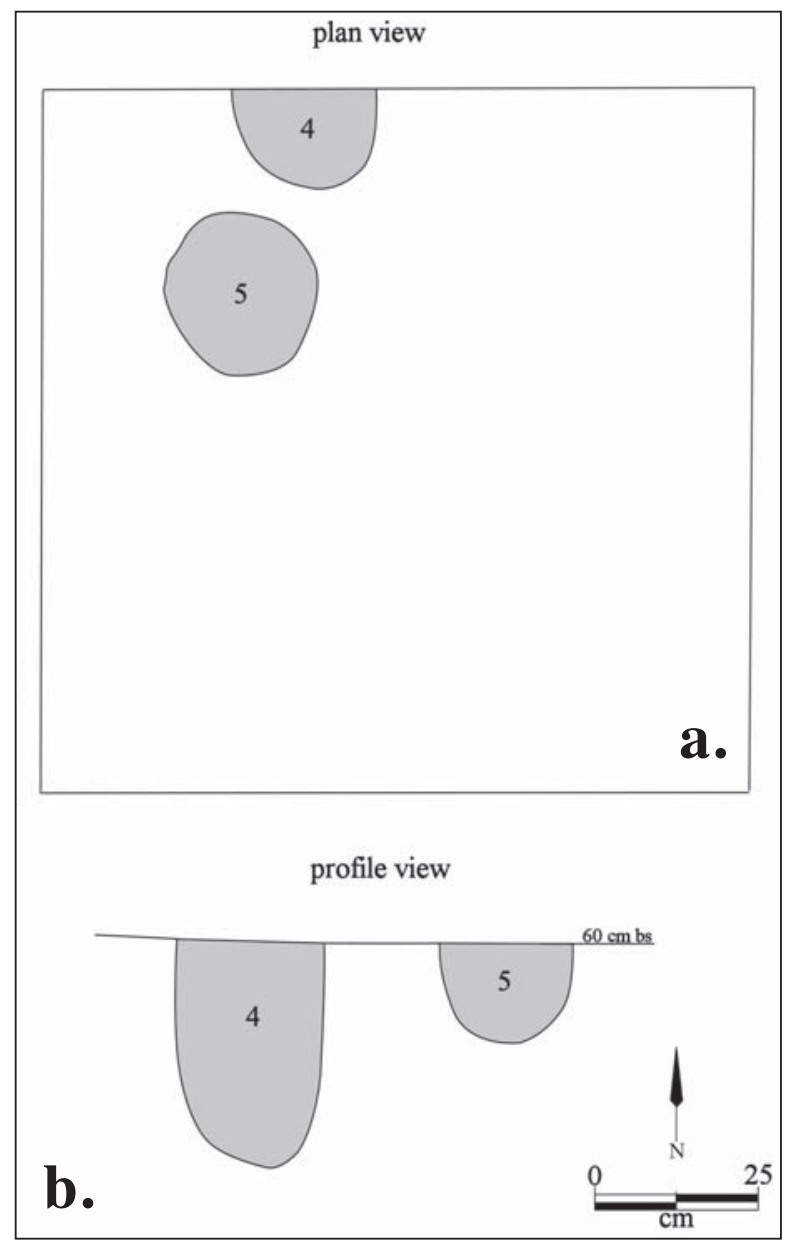

Figure 3. Post hole features in Unit BC-2 at the Bowles Creek site: a, plan view; b, profiles. 
Artifacts recovered in Unit BC-2 include plain and decorated ceramic vessel sherds ( $\mathrm{n}=144)$, animal bone $(n=20)$, wood charcoal $(n=11)$, charred nutshells $(n=3)$, lithic debris $(n=3)$, and a polished quartzite pebble resting at $31 \mathrm{~cm}$ bs. The most concentrated deposits of archaeological material culture remains occur between $10-30 \mathrm{~cm}$ bs (Table 3), with animal bone pieces most common between $30-40 \mathrm{~cm}$ bs; the majority of the wood charcoal and all of the nutshell came from the fill of the Stain 4 and 5 post holes.

Table 3. Distribution of artifacts from the $1 \times 1 \mathrm{~m}$ unit at the Bowles Creek site.

\begin{tabular}{lllllllll}
\hline $\begin{array}{l}\text { Depth } \\
(\mathrm{cm} \mathrm{bs})\end{array}$ & PS & DS & AB & WC & NS & LD & Other & N \\
\hline $0-10$ & 7 & 12 & - & - & - & - & - & 19 \\
$10-20$ & 25 & 26 & - & - & - & - & - & 51 \\
$20-30$ & 19 & 35 & 2 & - & - & - & - & 56 \\
$30-40$ & 7 & 6 & 11 & 1 & - & 1 & $1 *$ & 27 \\
$40-43$ & 2 & 1 & 1 & - & - & 2 & - & 6 \\
Features & - & 4 & 6 & 10 & 3 & - & - & 23 \\
\hline Totals & 60 & 84 & 20 & 11 & 3 & 3 & 1 & 182 \\
\hline
\end{tabular}

PS=plain sherds; DS=decorated sherds; $\mathrm{AB}=$ animal bone; $\mathrm{WC}=$ wood charcoal; $\mathrm{NS}=$ nutshell; $\mathrm{LD}=$ lithic debris *polished pebble

The ceramic vessel sherds from the Bowles Creek site are primarily from grog-tempered vessels (88.4 percent), and the remaining 11.6 percent of the sherds are from bone-tempered vessels (Table 4). Notably, none of the fine ware sherds are from bone-tempered vessels. Previous samples of ceramic vessel sherds from the Bowles Creek site had 9.9 percent (Perttula et al. 2016) and 10.7 percent (Perttula and Stingley 2016a) bone-tempered wares.

Table 4. Ceramic Wares at the Bowles Creek site.

\begin{tabular}{lccc}
\hline Ware & Grog-tempered & Bone-tempered & N \\
\hline Plain & 91 & 16 & 107 \\
Utility & 131 & 15 & 146 \\
Fine & 15 & - & 15 \\
\hline Totals & 237 & 31 & 268 \\
\hline
\end{tabular}

Of the 161 decorated sherds in this assemblage, 90.7 percent are from utility ware vessels (see Table 4). Only 9.3 percent of the decorated sherds are from fine ware engraved vessels. The plain to decorated sherd ratio of the assemblage is 0.66 .

The utility ware sherds at the Bowles Creek site are dominated by sherds from brushed vessels, probably Bullard Brushed jars, either as the sole decorative method ( $n=91,80.5$ percent of the utility wares), or in combination with appliqued, incised, or punctated decorative elements $(n=6,5.3$ percent) (Table 5). About 77.6 percent of all the decorated sherds in this assemblage have brushed decorative elements. 
Table 5. Decorative methods and elements in the January 2016 ceramic sherd sample from the Bowles Creek site.

\begin{tabular}{llll}
\hline Decorative Method and Element & Rim & Body & N \\
\hline
\end{tabular}

\section{Utility Ware}

\section{Brushed}

horizontal brushed

opposed brushed

parallel brushed

$\begin{array}{lll}4 & - & 4 \\ - & 3 & 3 \\ - & 106 & 106 \\ - & & \\ - & 1 & 1 \\ - & & \\ - & 1 & 1 \\ - & 1 & 1 \\ & 2 & 2\end{array}$

\section{Brushed-Appliqued}

parallel brushed and straight appliqued ridge

\section{Brushed-Incised}

parallel brushed-incised marks and lines

parallel brushed and overlying diagonal incised lines

parallel brushed and overlying parallel incised lines

\section{Brushed-Punctated}

parallel brushed and circular punctated row through the brushing marks parallel brushed and tool punctated row through the brushing vertical brushed and adjacent tool punctated row

$\begin{array}{lll}- & 1 & 1 \\ - & 1 & 1 \\ - & 1 & 1 \\ - & & \\ - & 2 & 2 \\ - & & \\ - & 1 & 1 \\ - & 1 & 7 \\ - & 7 & 7 \\ & 7 & \\ - & & 2 \\ - & 2 & \\ & & \\ & 5 & 5\end{array}$

tool punctated rows

\section{Fine Ware}

\section{Engraved}

curvilinear engraved lines with excised tick marks horizontal engraved lines

horizontal engraved lines and excised tick marks horizontal and diagonal engraved lines horizontal and vertical engraved lines horizontal line and vertical bracket parallel engraved lines straight engraved line

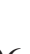

\section{Grooved}

Incised

curvilinear incised line

diagonal opposed incised lines

parallel incised lines

Neck Banded

parallel neck bands

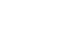

5

\begin{tabular}{lllll}
\hline Totals & 7 & 154 & 161 \\
\hline
\end{tabular}


Three of the brushed-incised sherds are from Spradley Brushed-Incised vessels (see Table 5). They have either diagonal or parallel incised lines overlying parallel brushing marks. Two utility ware sherds are from La Rue Neck Banded jars, and two others are from Lindsey Grooved vessels. Sherds with incised or punctated decorative elements comprise 11.0 and 3.4 percent of the utility wares, respectively, from the Bowles Creek site.

In the fine wares, two of the sherds from the Bowles Creek site are from Poynor Engraved vessels, although the specific variety (see Perttula 2011:Figure 6-64) cannot be determined because of the small size of the sherds; the most likely possibility is var. Freeman, the latest of the Poynor Engraved varieties. Both sherds are from carinated bowls that have a single horizontal engraved line above the carination, and with an engraved vertical bracket (Figure 4a-b). A rim sherd in the assemblage has a single horizontal engraved line beneath the lip, and a zone of closely-spaced vertical engraved lines (Figure 4d).

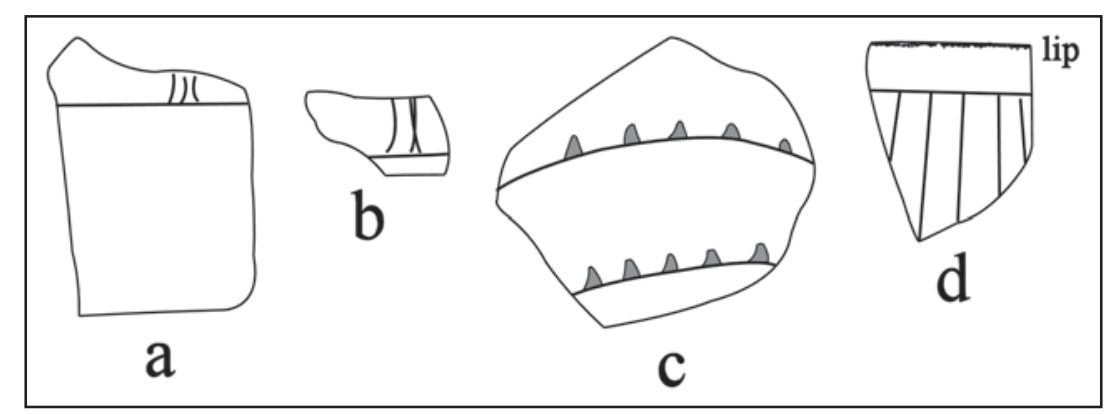

Figure 4. Selected decorative elements in engraved sherds from the Bowles Creek site: a-b, Poynor Engraved; c, Patton Engraved; d, unidentified engraved rim sherd.

Two of the engraved sherds are from Patton Engraved vessels (see Figure 4c). The first has curvilinear engraved lines with excised tick marks, and may be from either a Patton Engraved, var. Freeman or var. Fair vessel (see Perttula 2011:Figure 6-66c-d). A rim sherd in ST 41 has a horizontal engraved line beneath the lip, and there are small excised tick marks on this engraved line.

A single grog-tempered elbow pipe sherd was recovered between $30-35 \mathrm{~cm}$ bs in ST 40. It is a Var. C elbow pipe form (see Perttula 2011:Figure 6-23), with horizontal incised lines on the pipe stem beneath the lip, and opposed horizontal lines along the remainder of the pipe stem, running underneath the base of the pipe bowl. Var. C elbow pipe forms in the upper Neches River basin were made between ca. A.D. 1400-1650 (Perttula 2011:215).

\section{Cornfield (41CE476)}

Work at the Cornfield site in January 2016 consisted of the excavation of 18 shovel tests across a ca. $125 \times 80 \mathrm{~m}$ area of the landform (Figure 5); 16 of these shovel tests contained artifacts from an ancestral Caddo occupation. The archaeological deposits consist of a ca. 30-71 cm thick sandy loam deposit overlying a B-horizon clay, and Caddo ceramic vessel sherds were recovered from $0-60 \mathrm{~cm}$ bs in the shovel tests (Table 6). The highest densities of ceramic sherds occur in the southern and western part of the landform in ST B-6, ST 476-5, and ST 476-7 (see Figure 5), and were particularly concentrated between $20-40 \mathrm{~cm}$ bs $(\mathrm{n}=16)$ in ST 476-7. 


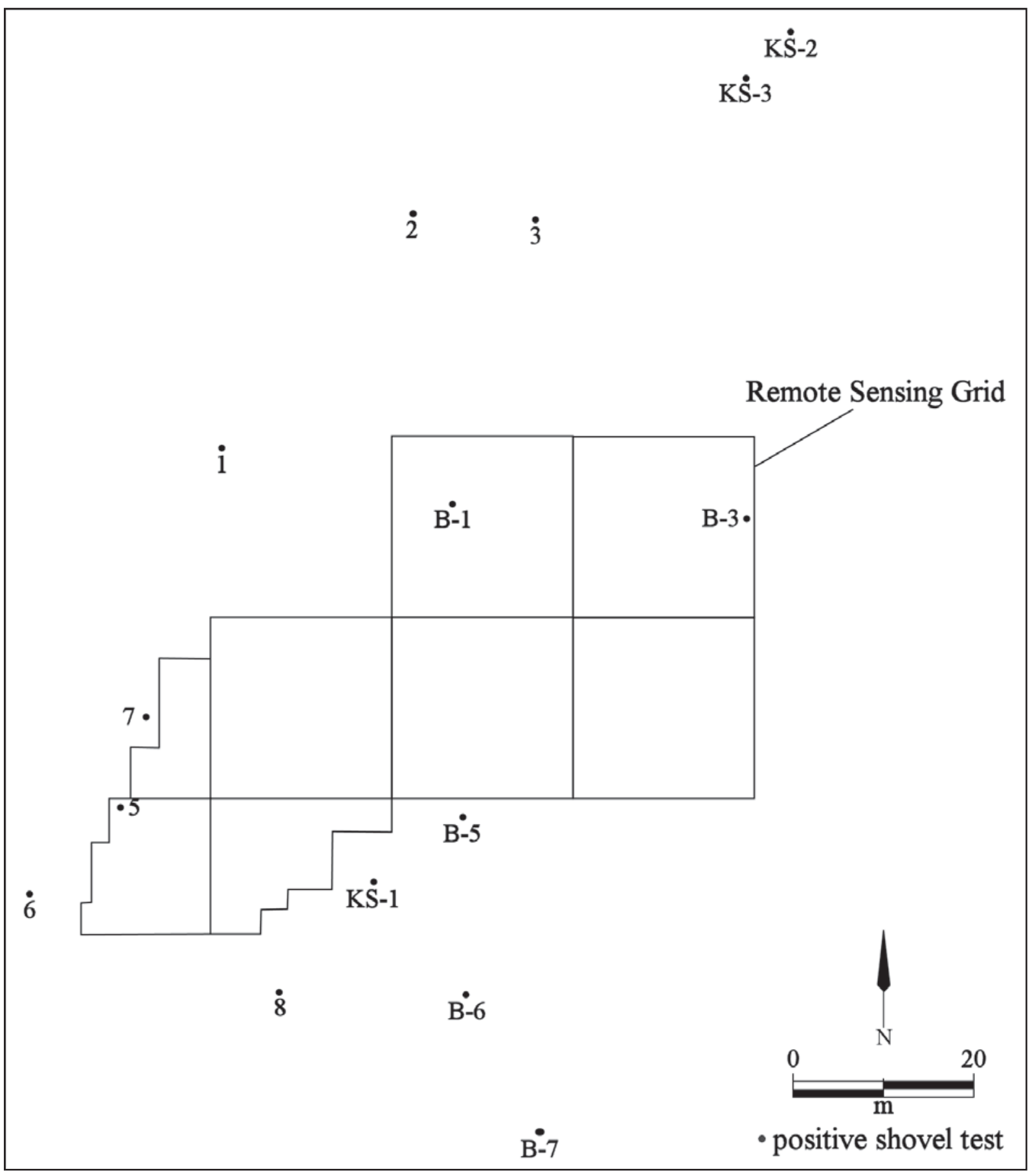

Figure 5. Map of the Cornfield site showing shovel test locations and the remote sensing grid of $20 \times 20$ m units. 
Table 6. Descriptions of positive shovel tests at the Cornfield site.

\begin{tabular}{|c|c|c|}
\hline ST Number & Description & Artifacts \\
\hline B-1 & $\begin{array}{l}0-71 \mathrm{~cm}, \text { reddish-brown sandy loam; } \\
71-73 \mathrm{~cm}+\text {, red clay }\end{array}$ & $\begin{array}{l}\text { ceramic sherds, } 0-20 \\
\mathrm{~cm} \text { bs }\end{array}$ \\
\hline B-2 & $\begin{array}{l}\text { 0-69 cm, reddish-brown sandy loam; } \\
69-71 \mathrm{~cm}+\text {, red clay }\end{array}$ & $\begin{array}{l}\text { heat-modified } \\
\text { sandstone rock, } 57 \mathrm{~cm} \\
\text { bs (bottom depth) }\end{array}$ \\
\hline B-3 & $\begin{array}{l}0-65 \mathrm{~cm}, \text { dark reddish-brown sandy loam; } \\
65-68 \mathrm{~cm}+\text {, dark red clay }\end{array}$ & $\begin{array}{l}\text { one ground stone tool, } \\
0-20 \mathrm{~cm} \mathrm{bs}\end{array}$ \\
\hline B-5 & $\begin{array}{l}\text { 0-66 cm, dark reddish-brown sandy loam; } \\
66-69 \mathrm{~cm}+\text {, dark red clay }\end{array}$ & $\begin{array}{l}\text { ceramic sherds, } 0-60 \\
\text { cm bs }\end{array}$ \\
\hline B-6 & $\begin{array}{l}0-56 \mathrm{~cm} \text {, dark reddish-brown sandy loam; } \\
56-58 \mathrm{~cm}+\text {, dark red clay }\end{array}$ & $\begin{array}{l}\text { ceramic sherds, } 0-60 \\
\mathrm{~cm} \text { bs }\end{array}$ \\
\hline B-7 & $\begin{array}{l}0-51 \mathrm{~cm}, \text { reddish-brown sandy loam; } \\
51-54 \mathrm{~cm}+\text {, red clay }\end{array}$ & $\begin{array}{l}\text { ceramic sherds, } 0-40 \\
\mathrm{~cm} \text { bs }\end{array}$ \\
\hline KS-1 & $\begin{array}{l}0-55 \mathrm{~cm} \text {, dark reddish-brown sandy losm; } \\
55-60 \mathrm{~cm}+\text {, red clay }\end{array}$ & $\begin{array}{l}\text { ceramic sherds, } 20-40 \\
\mathrm{~cm} \text { bs }\end{array}$ \\
\hline KS-2 & $\begin{array}{l}0-40 \mathrm{~cm}, \text { reddish-brown sandy loam; } \\
40-45 \mathrm{~cm}+\text {, red clay }\end{array}$ & $\begin{array}{l}\text { ceramic sherds, } 20-40 \\
\mathrm{~cm} \text { bs }\end{array}$ \\
\hline KS-3 & $\begin{array}{l}\text { 0-30 cm, reddish-brown sandy loam; } \\
30-36 \mathrm{~cm}+\text {, red clay }\end{array}$ & $\begin{array}{l}\text { ceramic sherds, } 0-30 \\
\mathrm{~cm} \text { bs }\end{array}$ \\
\hline ST 476-1 & $\begin{array}{l}0-47 \mathrm{~cm}, \text { reddish-brown sandy loam; } \\
47-50 \mathrm{~cm}+\text {, red clay }\end{array}$ & $\begin{array}{l}\text { ceramic sherds, } 0-20 \\
\mathrm{~cm} \text { bs; lithic debris, } \\
20-40 \mathrm{~cm} \text { bs }\end{array}$ \\
\hline ST 476-2 & 0-40 $\mathrm{cm}+$, reddish-brown sandy loam & ceramic sherd, $20-40 \mathrm{~cm}$ bs \\
\hline ST $476-3$ & $0-40 \mathrm{~cm}+$, reddish-brown sandy loam & ceramic sherds, $0-20 \mathrm{~cm}$ bs \\
\hline ST 476-5 & $\begin{array}{l}0-28 \mathrm{~cm} \text {, yellowish-brown sandy loam; } \\
28-50 \mathrm{~cm}+\text {, reddish-brown sandy loam }\end{array}$ & $\begin{array}{l}\text { ceramic sherds, } 0-40 \\
\mathrm{~cm} \text { bs; lithic debris, } \\
20-40 \mathrm{~cm} \text { bs }\end{array}$ \\
\hline ST 476-6 & $\begin{array}{l}\text { 0-30 cm, yellowish-brown sandy loam; } \\
30-40 \mathrm{~cm}+\text {, reddish-brown sandy loam }\end{array}$ & $\begin{array}{l}\text { ceramic sherds, } 0-20 \\
\text { cm bs }\end{array}$ \\
\hline ST 476-7 & $\begin{array}{l}\text { 0-33 cm, yellowish-brown sandy loam; } \\
33-50 \mathrm{~cm}+\text {, reddish-brown sandy loam }\end{array}$ & $\begin{array}{l}\text { ceramic sherds, } 0-50 \\
\mathrm{~cm} \text { bs }\end{array}$ \\
\hline ST 476-8 & $\begin{array}{l}0-26 \mathrm{~cm}, \text { yellowish-brown sandy loam; } \\
26-40 \mathrm{~cm}+\text {, reddish-brown sandy loam }\end{array}$ & $\begin{array}{l}\text { ceramic sherd, } 20-40 \\
\text { cm bs }\end{array}$ \\
\hline
\end{tabular}


Fifteen of the 18 shovel tests excavated at the Cornfield site in January 2016 contained prehistoric archaeological deposits and ceramic and/or lithic artifacts (Table 7). These cover an area of ca. $130 \times 80$ $\mathrm{m}$, or ca.2.6 acres, but it is likely that the overall extent of the site is larger, given that only three of the shovel tests did not contain any ancestral Caddo artifacts. The mean artifact density is 4.73 artifacts per positive shovel test, or ca. 37.8 artifacts per square meter of archaeological deposits. The highest artifact densities are in ST 476-7 and ST B-6.

Table 7. Distribution of artifacts from the positive shovel tests at the Cornfield site.

\begin{tabular}{lccccc}
\hline ST No. & Plain Sherds & Decorated Sherds & Lithic Debris & Tool & N \\
\hline $476-1$ & 1 & 4 & 1 & - & 6 \\
$476-2$ & - & 1 & - & - & 1 \\
$476-3$ & 2 & - & - & - & 2 \\
$476-5$ & 3 & 5 & 1 & - & 9 \\
$476-6$ & - & 4 & - & - & 4 \\
$476-7$ & 7 & 12 & - & - & 19 \\
$476-8$ & 1 & - & - & - & 1 \\
B-1 & - & 3 & - & - & 3 \\
B-3 & - & - & - & 1 & 1 \\
B-5 & - & 3 & - & - & 3 \\
B-6 & 5 & 7 & - & - & 12 \\
B-7 & 1 & 1 & - & - & 2 \\
KS-1 & - & 1 & - & - & 1 \\
KS-2 & 3 & - & - & - & 3 \\
KS-3 & - & 4 & - & - & 4 \\
\hline Totals & 23 & 45 & 2 & 1 & 71 \\
\hline
\end{tabular}

The lithic artifacts recovered in the shovel tests consist of two non-cortical pieces of petrified wood lithic debris and a ground stone tool from $0-20 \mathrm{~cm}$ bs in ST B-3 (see Table 7). The ground stone tool is a ferruginous sandstone bi-pitted stone.

The 68 ceramic sherds from the shovel testing of the Cornfield site are primarily from grog-tempered vessels (92.6 percent), with the remaining 7.4 percent from bone-tempered vessels (Table 8); none of the fine ware sherds are from bone-tempered vessels. More than 93 percent of the decorated sherds are from utility ware vessels. The plain to decorated sherd ratio in this assemblage is 0.51 .

Table 8. Ceramic Wares at the Cornfield site.

\begin{tabular}{lccc}
\hline Ware & Grog-tempered & Bone-tempered & N \\
\hline Plain & 21 & 2 & 23 \\
Utility & 39 & 3 & 42 \\
Fine & 3 & - & 3 \\
\hline Totals & 63 & 5 & 68 \\
\hline
\end{tabular}


Sherds from brushed and brushed-incised utility ware vessels comprise 69 percent and 11 percent, respectively, of all the decorated sherds from the Cornfield site. They also represent 86 percent of the utility wares in the assemblage (Table 9). Other utility wares have appliqued ( $\mathrm{n}=1,2.4$ percent of the utility wares), incised ( $n=3,7.1$ percent), and tool punctated ( $n=2,4.8$ percent) decorative elements.

Table 9. Decorative methods and elements in the January 2016 ceramic sherd sample from the Cornfield site.

Decorative Method and Element Rim Body N

\section{Utility Ware}

\section{Appliqued}

straight appliqued fillet

$\begin{array}{lll}- & 1 & 1\end{array}$

\section{Brushed}

opposed brushed

parallel brushed

$\begin{array}{rrr}- & 1 & 1 \\ - & 29 & 29 \\ 1 & - & 1\end{array}$

vertical brushed

Brushed-Incised

parallel brushed-incised marks and lines

Incised

parallel incised lines

\section{Punctated}

linear tool punctated rows

tool punctated row

$\begin{array}{lll}- & 1 & 1 \\ - & 1\end{array}$

\section{Fine Ware}

\section{Engraved}

horizontal engraved line with excised tick marks

straight engraved line

Totals

$\begin{array}{lll}- & 1 & 1\end{array}$

$\begin{array}{lll}- & 2 & 2\end{array}$

1

44

One of the engraved fine ware sherds is from a Patton Engraved vessel. It has a single horizontal engraved line with excised linear marks on either side of the engraved line (Figure 6). 


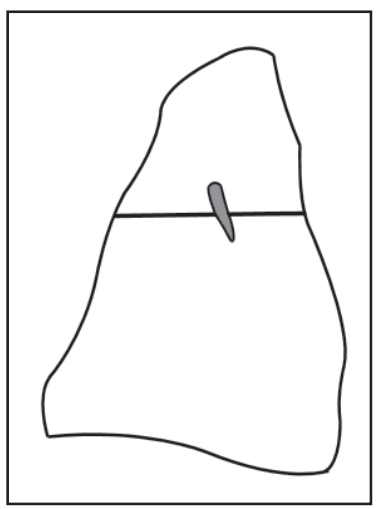

Figure 6. Patton Engraved body sherd from ST476-7, 20-40 cm bs, at the Cornfield site.

\section{Peach Orchard (41CE477)}

Following the systematic surface collections at the Peach Orchard reported by Perttula and Stingley (2016b), a single shovel test was excavated in each of the $10 \times 10 \mathrm{~m}$ surface collection units (Figure 7). Each shovel test contained ancestral Caddo artifacts, primarily ceramic vessel sherds (Table 10).

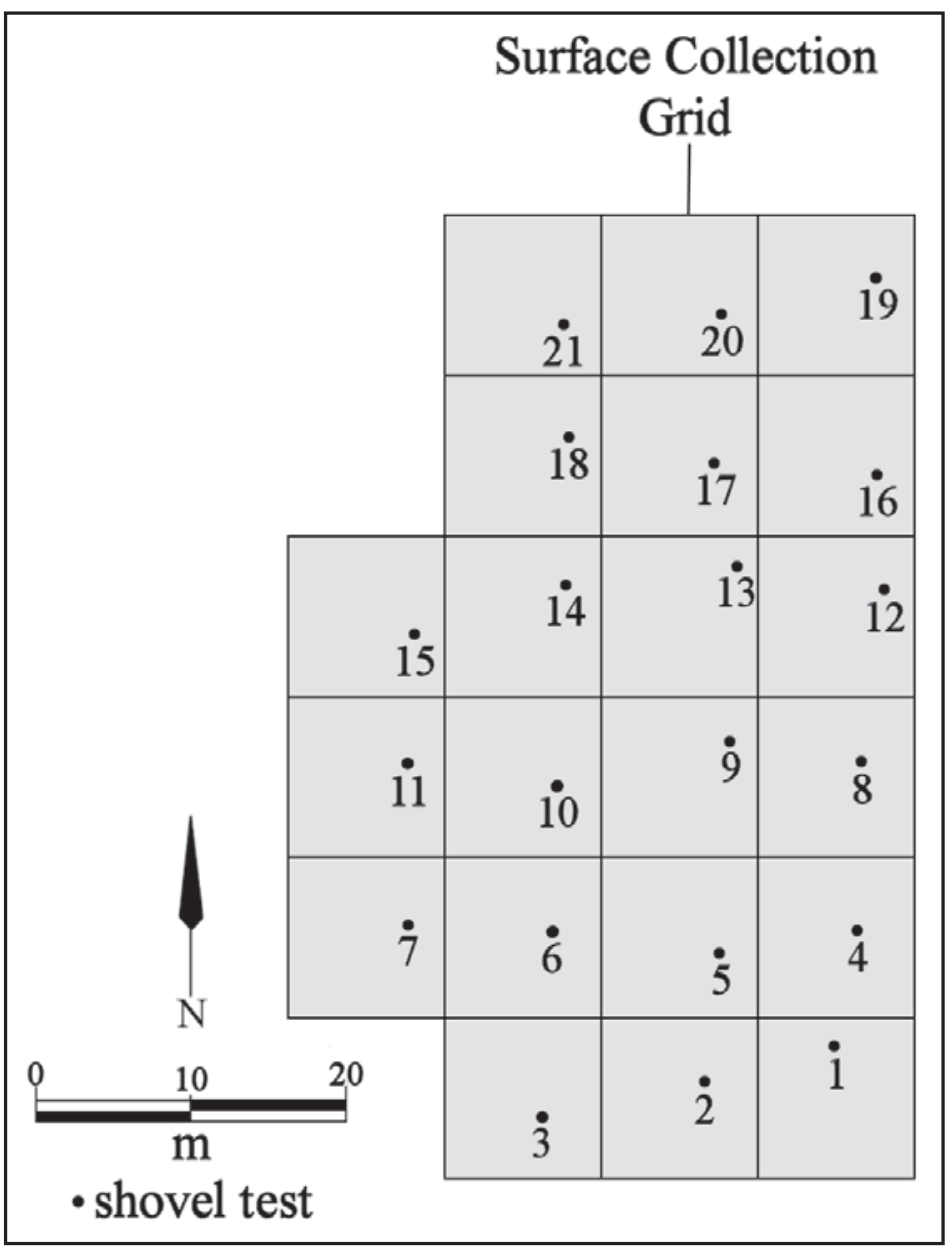

Figure 7. Map of the Peach Orchard site surface collection grid and shovel tests 1-21. 
Table 10. Descriptions of positive shovel tests at the Peach Orchard site.

\begin{tabular}{|c|c|c|}
\hline ST Number & Description & Artifacts \\
\hline ST 477-1 & $\begin{array}{l}0-16 \mathrm{~cm}, \text { reddish-brown sandy loam; } \\
16-19 \mathrm{~cm}+\text {, red clay }\end{array}$ & $\begin{array}{l}\text { ceramic sherds, } 0-20 \\
\mathrm{~cm} \text { bs }\end{array}$ \\
\hline ST 477-2 & $\begin{array}{l}0-14 \mathrm{~cm}, \text { reddish-brown sandy loam; } \\
14-18 \mathrm{~cm}+\text {, red clay }\end{array}$ & $\begin{array}{l}\text { ceramic sherd, } 0-18 \\
\mathrm{~cm} \text { bs }\end{array}$ \\
\hline ST 477-3 & $\begin{array}{l}0-27 \mathrm{~cm}, \text { reddish-brown sandy loam; } \\
27-30 \mathrm{~cm}+\text {, red clay }\end{array}$ & $\begin{array}{l}\text { ceramic sherds, } 0-20 \\
\mathrm{~cm} \text { bs; lithic debris, } 0 \text { - } \\
30 \mathrm{~cm} \text { bs }\end{array}$ \\
\hline ST 477-4 & $\begin{array}{l}0-18 \mathrm{~cm}, \text { reddish-brown sandy loam; } \\
18-20 \mathrm{~cm}+\text {, red clay }\end{array}$ & $\begin{array}{l}\text { ceramic sherds, } 0-20 \\
\mathrm{~cm} \text { bs }\end{array}$ \\
\hline ST 477-5 & $\begin{array}{l}0-17 \mathrm{~cm}, \text { reddish-brown sandy loam; } \\
17-18 \mathrm{~cm}+\text {, red clay }\end{array}$ & $\begin{array}{l}\text { ceramic sherds, } 0-17 \\
\mathrm{~cm} \text { bs }\end{array}$ \\
\hline ST 477-6 & $\begin{array}{l}0-18 \mathrm{~cm}, \text { reddish-brown sandy loam; } \\
18-20 \mathrm{~cm}+\text {, red clay }\end{array}$ & $\begin{array}{l}\text { ceramic sherds, } 0-20 \\
\mathrm{~cm} \text { bs; burned clay, } 0- \\
20 \mathrm{~cm} \text { bs }\end{array}$ \\
\hline ST $477-7$ & $\begin{array}{l}0-20 \mathrm{~cm}, \text { reddish-brown sandy loam; } \\
20-22 \mathrm{~cm}+\text {, red clay }\end{array}$ & $\begin{array}{l}\text { ceramic sherds, } 0-20 \\
\mathrm{~cm} \text { bs }\end{array}$ \\
\hline ST 477-8 & $\begin{array}{l}0-25 \mathrm{~cm}, \text { reddish-brown sandy loam; } \\
25-26 \mathrm{~cm}+\text {, red clay }\end{array}$ & $\begin{array}{l}\text { ceramic sherds, } 0-26 \\
\mathrm{~cm} \text { bs; lithic debris, } 0- \\
26 \mathrm{~cm} \text { bs }\end{array}$ \\
\hline ST 477-9 & No description available & ceramic sherds \\
\hline ST 477-10 & $\begin{array}{l}\text { 0-30 cm, reddish-brown sandy loam; } \\
30-32 \mathrm{~cm}+\text {, red clay }\end{array}$ & $\begin{array}{l}\text { ceramic sherds, } 0-32 \\
\mathrm{~cm} \text { bs; lithic debris, } \\
20-32 \mathrm{~cm} \text { bs; animal } \\
\text { bone, } 20-32 \mathrm{~cm} \text { bs; } \\
\text { historic bottle glass } \\
\text { sherd, } 20-32 \mathrm{~cm} \text { bs }\end{array}$ \\
\hline ST $477-11$ & $\begin{array}{l}0-14 \mathrm{~cm}, \text { reddish-brown sandy loam; } \\
14-16 \mathrm{~cm}+\text {, red clay }\end{array}$ & $\begin{array}{l}\text { ceramic sherd, } 0-14 \\
\mathrm{~cm} \text { bs; lithic debris, } 0 \text { - } \\
14 \mathrm{~cm} \text { bs }\end{array}$ \\
\hline ST 477-12 & $\begin{array}{l}0-16 \mathrm{~cm}, \text { reddish-brown sandy loam; } \\
16-20 \mathrm{~cm}+\text {, red clay }\end{array}$ & $\begin{array}{l}\text { ceramic sherds, } 0-20 \\
\mathrm{~cm} \text { bs }\end{array}$ \\
\hline ST 477-13 & No description available & ceramic sherds \\
\hline ST 477-14 & $\begin{array}{l}\text { 0-29 cm, reddish-brown sandy loam; } \\
29-31 \mathrm{~cm}+\text {, red clay }\end{array}$ & $\begin{array}{l}\text { ceramic sherd, } 0-20 \\
\mathrm{~cm} \text { bs }\end{array}$ \\
\hline
\end{tabular}


Table 10. Descriptions of positive shovel tests at the Peach Orchard site, cont.

\begin{tabular}{|c|c|c|}
\hline ST Number & Description & Artifacts \\
\hline ST $477-15$ & $\begin{array}{l}0-24 \mathrm{~cm}, \text { reddish-brown sandy loam; } \\
24-28 \mathrm{~cm}+, \text { red sandy clay }\end{array}$ & $\begin{array}{l}\text { ceramic sherd, } 0-20 \\
\mathrm{~cm} \text { bs }\end{array}$ \\
\hline ST $477-16$ & $\begin{array}{l}\text { 0-29 cm, reddish-brown sandy loam; } \\
29-31 \mathrm{~cm}+, \text { red clay }\end{array}$ & $\begin{array}{l}\text { ceramic sherds, } 0-31 \\
\mathrm{~cm} \text { bs; lithic debris, } 0 \text { - } \\
20 \mathrm{~cm} \text { bs }\end{array}$ \\
\hline ST $477-17$ & $\begin{array}{l}0-20 \mathrm{~cm}, \text { reddish-brown sandy loam; } \\
20-22 \mathrm{~cm}+, \text { red clay }\end{array}$ & $\begin{array}{l}\text { ceramic sherds, } 0-20 \\
\text { cm bs; animal bone, } \\
0-20 \mathrm{~cm} \text { bs }\end{array}$ \\
\hline ST $477-18$ & $\begin{array}{l}0-30 \mathrm{~cm}, \text { reddish-brown sandy loam; } \\
30-32 \mathrm{~cm}+, \text { red clay }\end{array}$ & $\begin{array}{l}\text { ceramic sherds, } 0-32 \\
\mathrm{~cm} \text { bs; lithic debris, } \\
20-32 \mathrm{~cm} \text { bs }\end{array}$ \\
\hline ST $477-19$ & $\begin{array}{l}0-30 \mathrm{~cm}, \text { reddish-brown sandy loam; } \\
30-32 \mathrm{~cm}+\text {, red clay }\end{array}$ & $\begin{array}{l}\text { ceramic sherds, } 0-20 \\
\mathrm{~cm} \text { bs; lithic debris, } 0 \text { - } \\
20 \mathrm{~cm} \text { bs }\end{array}$ \\
\hline ST 477-20 & $\begin{array}{l}0-26 \mathrm{~cm}, \text { reddish-brown sandy loam; } \\
26-28 \mathrm{~cm}+\text {, red clay }\end{array}$ & $\begin{array}{l}\text { ceramic sherds, } 0-20 \\
\text { cm bs }\end{array}$ \\
\hline ST $477-21$ & $\begin{array}{l}0-28 \mathrm{~cm}, \text { reddish-brown sandy loam; } \\
28-30 \mathrm{~cm}+\text {, red clay }\end{array}$ & $\begin{array}{l}\text { ceramic sherds, } 0-20 \\
\text { cm bs }\end{array}$ \\
\hline
\end{tabular}

The archaeological deposits at the site are shallow, ranging from $14-30 \mathrm{~cm}$ bs of sandy loam sediments overlying a red clay B-horizon (see Table 10). These deposits are shallowest in the southern part of the systematic surface collection grid. The highest densities of artifacts occur in the core area of the surface collection grid (Perttula and Stingley 2016b:Figure 4), and the overall density is ca. 6.8 artifacts per positive shovel test and ca. 54 artifacts per square meter of archaeological deposits (Table 11). Ceramic vessel sherds comprise 91 percent of the recovered artifacts, and lithic debris another 6.3 percent of the assemblage. There were also burned clay $(n=1)$, animal bone $(n=2)$, and one sherd of $19^{\text {th }}$ century green wine bottle glass in ST 477-10.

Table 11. Distribution of artifacts from the positive shovel tests at the Peach Orchard site.

\begin{tabular}{llllllll}
\hline ST No. & PS & DS & BC & AB & LD & HIST & N \\
\hline $477-1$ & 1 & 2 & - & - & - & - & 3 \\
$477-2$ & - & 1 & - & - & - & - & 1 \\
$477-3$ & 1 & 2 & - & - & 2 & - & 5 \\
$477-4$ & 2 & 4 & - & - & - & - & 6 \\
$477-5$ & 2 & 1 & - & - & - & - & 3 \\
$477-6$ & 4 & 3 & 1 & - & - & - & 8 \\
$477-7$ & 3 & 1 & - & - & - & - & 4 \\
$477-8$ & 2 & 6 & - & - & 1 & - & 9
\end{tabular}


Table 11. Distribution of artifacts from the positive shovel tests at the Peach Orchard site.

\begin{tabular}{llllllll}
\hline ST No. & PS & DS & BC & AB & LD & HIST & N \\
\hline $477-9$ & 4 & 15 & - & - & - & - & 19 \\
$477-10$ & 1 & 4 & - & 1 & 1 & 1 & 8 \\
$477-11$ & - & 1 & - & - & 2 & - & 3 \\
$477-12$ & 2 & 6 & - & - & - & - & 8 \\
$477-13$ & 6 & 21 & - & - & - & - & 1 \\
$477-14$ & - & 1 & - & - & - & - & 1 \\
$477-15$ & 1 & - & - & - & - & - & 7 \\
$477-16$ & 8 & 6 & - & - & 1 & - & 4 \\
$477-17$ & 2 & 4 & - & 1 & - & - & 4 \\
$477-18$ & 1 & 2 & - & - & 1 & - & 3 \\
$477-19$ & 2 & 1 & - & - & 1 & - & 4 \\
$477-20$ & - & 4 & - & - & - & - & 143 \\
$477-21$ & - & 3 & - & - & - & - & 1 \\
\hline Totals & 42 & 88 & 1 & 2 & 9 & 1 & 4 \\
\hline
\end{tabular}

PS=plain sherds; $\mathrm{DS}=$ decorated sherds; $\mathrm{BC}=$ burned clay; $\mathrm{AB}=$ animal bone; $\mathrm{LD}=$ lithic debris; $\mathrm{HIST}=$ historic artifacts

Additional numbers of artifacts, almost exclusively ceramic vessel sherds, were collected from the systematic surface collection grid at the Peach Orchard site (Table 12). These supplement the artifact collection totals reported in Perttula and Stingley (2016b).

Table 12. Additional artifacts recovered in systematic surface collection grid at the Peach Orchard site.

\begin{tabular}{lcccc}
\hline Grid Unit \# & Plain Sherds & Decorated Sherds & Lithic Debris & N \\
\hline 1 & 5 & 6 & - & 11 \\
2 & - & 8 & - & 8 \\
19 & 2 & 8 & - & 10 \\
20 & 4 & 9 & 1 & 14 \\
\hline Totals & 11 & 31 & 1 & 43 \\
\hline
\end{tabular}

More than 97 percent of the sherds in this assemblage from the Peach Orchard site are from grogtempered vessels (Table 13). Only 2.3 percent of the sherds are from bone-tempered vessels; none of the fine ware sherds are from bone-tempered vessels.

Table 13. Ceramic Wares at the Peach Orchard site.

\begin{tabular}{lccc}
\hline Ware & Grog-tempered & Bone-tempered & N \\
\hline Plain & 51 & 2 & 53 \\
Utility & 110 & 2 & 112 \\
Fine & 8 & - & 8 \\
\hline Totals & 169 & 4 & 173 \\
\hline
\end{tabular}


Of the 120 decorated sherds in the assemblage, 93.3 percent are from utility ware vessels (see Table 13). The plain to decorated sherd ratio of the assemblage is a low 0.44 .

More than 78 percent of the decorated sherds in this assemblage from the Peach Orchard site are from brushed vessels (Table 14), likely Bullard Brushed jars. Another 3.3 percent have brushing marks in combination with either incised or punctated elements; two of the brushed-incised sherds are from Spradley Brushed-Incised vessels with brushing marks and overlying diagonal or parallel incised lines.

Table 14. Decorative methods and elements in the January 2016 ceramic sherd sample from the Peach Orchard site.

\begin{tabular}{llll}
\hline Decorative Method and Element & Rim & Body & $\mathrm{N}$ \\
\hline
\end{tabular}

\section{Utility Ware}

Appliqued

opposed appliqued ridges

\section{Brushed}

diagonal brushed

horizontal brushed

opposed brushed

overlapping brushed

parallel brushed

vertical brushed

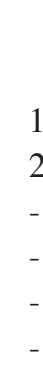

\section{Brushed-Incised}

parallel brushed-incised marks and lines

parallel brushed and overlying diagonal incised lines

parallel brushed and overlying parallel incised lines

\section{Brushed-Punctated}

parallel brushed and tool punctated row through the brushing

\section{Grooved}

straight groove

Incised

parallel incised lines

\section{Pinched}

straight pinched ridge

\section{Punctated}

single fingernail punctate linear tool punctated row/rows tool punctated row/rows

$\begin{array}{ll}- & 1 \\ - & 2 \\ 1 & 1 \\ 1 & 1 \\ 88 & 88\end{array}$

11


Table 14. Decorative methods and elements in the January 2016 ceramic sherd sample from the Peach Orchard site, cont.

\begin{tabular}{llll}
\hline Decorative Method and Element & Rim & Body & N \\
\hline Fine Ware & & & \\
\hline $\begin{array}{l}\text { Engraved } \\
\text { curvilinear engraved lines } \\
\text { horizontal engraved line below the lip } \\
\text { opposed engraved lines } \\
\text { straight engraved line }\end{array}$ & - & 1 & 1 \\
$\begin{array}{l}\text { Engraved-Brushed } \\
\text { horizontal engraved line with excised tick marks and } \\
\text { horizontal brushing on body }\end{array}$ & - & 1 & 3 \\
Red-slipped & & 3 & 1 \\
ext. red-slipped surface & - & 1 & 1 \\
\hline \begin{tabular}{l} 
Totals \\
\hline
\end{tabular} & & & 1 \\
\hline
\end{tabular}

Other utility wares in this Peach Orchard assemblage include three Lindsey Grooved body sherds and one Killough Pinched body sherd (see Table 14). Sherds from incised vessels comprise only 1.8 percent of the utility wares, and sherds with tool or fingernail punctated elements account for only 5.4 percent of the utility wares.

Fine ware vessel sherds include sherds from engraved, engraved-brushed, and red-slipped vessels (see Table 14). These amount to 6.7 percent of the decorated sherds in this assemblage from the Peach Orchard site. The engraved-brushed sherd from the Peach Orchard site (Figure 8) could be from either a Patton Engraved (several varieties) or Poynor Engraved, var. Freeman vessel.

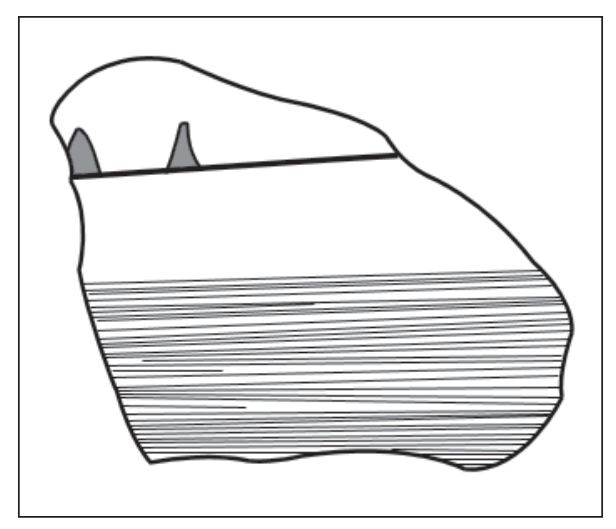

Figure 8. Engraved-brushed sherd from surface collection grid unit 19 at the Peach Orchard site. 


\section{Ceramic Assemblage Comparisons}

The ancestral Caddo ceramic assemblages from the Bowles Creek, Cornfield, and Peach Orchard sites are very similar with respect to the proportion of the different ceramic wares at the three sites, in the use of grog vs. bone as temper inclusions of choice in vessel manufacture, and in the composition of decorative methods and elements in the utility ware and fine ware vessels (Table 15). All three sites have Historic Caddo ceramic assemblages with Patton Engraved fine ware vessels, as well as Bullard Brushed, Spradley Brushed-Incised, and Lindsey Grooved utility wares. Sherds with brushed, brushed-incised, and brushed-punctated decorative elements dominate the assemblages at each of the sites, comprising between 81.1-83.5 percent of all of the decorated sherds; sherds from incised or punctated vessels comprise only 4.1-7.0 percent or 1.5-2.3 percent, respectively, of the decorated sherds in the three assemblages. Fine wares account for 7.7-9.5 percent of the decorated sherds at these Bowles Creek sites (Table 15).

Table 15. Ceramic sherd assemblage comparisons of the Bowles Creek, Cornfield, and Peach Orchard sites.

\begin{tabular}{|c|c|c|c|}
\hline Attribute & Bowles Creek & Cornfield & Peach Orchard \\
\hline No. of sherds & 1222 & 295 & 2346 \\
\hline No. of decorated sherds & 828 & 201 & 1676 \\
\hline Plain ware & $32.2 \%$ & $31.9 \%$ & $28.5 \%$ \\
\hline Utility ware & $62.5 \%$ & $61.7 \%$ & $65.4 \%$ \\
\hline Fine ware & $5.3 \%$ & $6.4 \%$ & $6.1 \%$ \\
\hline $\mathrm{P} / \mathrm{DR}$ & 0.47 & 0.47 & 0.40 \\
\hline Brushed/Plain Ratio & 1.72 & 1.72 & 2.09 \\
\hline Brushed/OWP Ratio & 7.14 & 5.59 & 7.91 \\
\hline Grog-tempered & $89.4 \%$ & $91.2 \%$ & $98.5 \%$ \\
\hline Bone-tempered & $10.6 \%$ & $8.8 \%$ & $1.5 \%$ \\
\hline Red-slipped & - & - & $0.1 \%$ \\
\hline Engraved & $7.0 \%$ & $9.0 \%$ & $8.1 \%$ \\
\hline Engraved-brushed & $0.1 \%$ & - & $0.2 \%$ \\
\hline Engraved-punctated & $0.2 \%$ & - & - \\
\hline Trailed & $0.4 \%$ & $0.5 \%$ & $0.1 \%$ \\
\hline Appliqued & - & $1.0 \%$ & $0.2 \%$ \\
\hline Brushed & $80.9 \%$ & $76.6 \%$ & $80.7 \%$ \\
\hline Brushed-Appliqued & $0.1 \%$ & - & $0.2 \%$ \\
\hline Brushed-Incised & $1.1 \%$ & $4.0 \%$ & $1.4 \%$ \\
\hline Brushed-Pinched & - & - & $0.1 \%$ \\
\hline Brushed-Punctated & $1.0 \%$ & $0.5 \%$ & $1.1 \%$ \\
\hline Grooved & $0.4 \%$ & $0.5 \%$ & $1.4 \%$ \\
\hline Grooved-Incised & - & - & $0.1 \%$ \\
\hline Grooved-Punctated & - & - & $0.1 \%$ \\
\hline Incised & $5.4 \%$ & $7.0 \%$ & $4.1 \%$ \\
\hline Incised-Punctated & $0.2 \%$ & - & $0.1 \%$ \\
\hline Neck Banded & $0.2 \%$ & - & $0.2 \%$ \\
\hline Pinched & $0.8 \%$ & - & $0.1 \%$ \\
\hline Punctated & $2.3 \%$ & $1.5 \%$ & $1.5 \%$ \\
\hline
\end{tabular}

$\mathrm{P} / \mathrm{DR}=$ plain/decorated sherd ratio; $\mathrm{OWP}=$ other wet paste sherds 
The Neche cluster of ceramic vessel sherd assemblages that have been studied to date includes Allen phase Historic Caddo sites on Bowles Creek, including the three sites that are the subject of this article, and one site on the Neches River (41CE291) as well as one Late Frankston phase (ca. A.D. 1560-1680) investigated component of the George C. Davis site (41CE19) on the northern part of the terrace east of the Neches River. These components have high proportions of brushed sherds to plain sherds and ratios of brushed to other wet paste sherds (Table 16); plain to decorated sherd ratios (P/DR) range from 0.12-0.47 for the Allen phase components and 0.82 for the one late Frankston phase component at the George C. Davis site. These assemblages are almost exclusively comprised of grog-tempered vessels, but differences between the sites in the proportion of bone-tempered vessels (either as the sole temper or in combination with grog) - and in the brushed/plain and brushed to other wet paste sherds - suggest that three contemporaneous groups of Allen phase sites are present in the Neche cluster. These groups (I, II, and III) also are notably different in brushed to plain sherd ratios (Table 16), but differ little with respect to the brushed/other wet paste sherd ratios, except in the case of the Group III and Group IV components on the Neches River.

Table 16. Ceramic sherd assemblage comparisons of Neche cluster sites, including 41CE291.

\begin{tabular}{|c|c|c|c|c|c|}
\hline Site & $\%$ Grog & $\%$ Bone & $\mathrm{P} / \mathrm{DR}$ & $\mathrm{B} / \mathrm{Pl}$ & B/OWP** \\
\hline \multicolumn{6}{|c|}{ Allen phase } \\
\hline \multicolumn{6}{|c|}{ Group I } \\
\hline 41CE293 & $98.1 *$ & $5.6^{*}$ & 0.12 & 7.50 & 5.70 \\
\hline 41CE474 & 97.1 & 2.9 & 0.30 & 3.08 & 9.25 \\
\hline 41CE477 & 98.5 & 1.5 & 0.40 & 2.09 & 7.91 \\
\hline \multicolumn{6}{|l|}{ Group II } \\
\hline $41 \mathrm{CE} 48$ & 84.2 & 27.7 & 0.31 & 2.43 & 5.48 \\
\hline 41CE20 & 98.4 & 14.3 & 0.40 & 2.07 & 5.0 \\
\hline 41CE475 & 89.5 & 10.5 & 0.47 & 1.72 & 7.07 \\
\hline 41CE476 & 91.2 & 8.8 & 0.47 & 1.72 & 5.59 \\
\hline \multicolumn{6}{|l|}{ Group III } \\
\hline 41CE291 & 97.4 & 2.6 & 0.30 & 1.94 & 1.84 \\
\hline \multicolumn{6}{|c|}{$\begin{array}{l}\text { Late Frankston phase } \\
\text { Group IV }\end{array}$} \\
\hline $\begin{array}{l}41 \mathrm{CE} 19, \\
\text { Northern } \\
\text { part of site }\end{array}$ & N/A & N/A & 0.82 & 0.78 & 1.90 \\
\hline
\end{tabular}

$\mathrm{P} / \mathrm{DR}=$ plain to decorated sherd ratio; $\mathrm{B} / \mathrm{Pl}=$ brushed/plain sherd ratio; $\mathrm{B} / \mathrm{OWP}=$ brushed/other wet paste sherd ratio *percentages will total to more than 100 percent because some sherds have more than one kind of temper

**sherds with multiple decorative elements (i.e., brushed-incised or brushed-punctated, etc.) are counted as both brushed and as other wet paste sherds

\section{Summary and Conclusions}

Archaeological investigations were completed at the Bowles Creek (41CE475), Cornfield (41CE476), and Peach Orchard (41CE477) sites in January 2016; these sites have been the scene of previous surface collection and shovel testing work (Perttula and Stingley 2016a, 2016b; Perttula et al. 2016). During this work, in addition to remote sensing investigations led by Dr. Duncan P. McKinnon at the three sites, 
intensive shovel testing was completed at all three sites, and a single 1 x $1 \mathrm{~m}$ unit was excavated at the Bowles Creek site. This work has helped clarify the extent and depth of the archaeological deposits at the three sites, and has gathered information on the character of habitation areas, the likelihood that cultural features are present, and the preservation of plant and animal remains in the archaeological deposits. The identification of two post holes to an ancestral Caddo structure in the excavated $1 \mathrm{x} 1 \mathrm{~m}$ unit at the Bowles Creek site is currently the best available archaeological evidence that indicates that Caddo structures are preserved there. Further archaeological work is planned at the three Historic Caddo, Allen phase sites, as well as other known ancestral Caddo sites on Bowles Creek (see Perttula et al. 2016) in East Texas.

\section{Acknowledgments}

We thank Tom Middlebrook, Bo Nelson and Mark Walters for their assistance with the shovel testing of the three sites, and their help with the excavation of the $1 \times 1 \mathrm{~m}$ unit at the Bowles Creek site. Duncan McKinnon and two of his students completed remote sensing investigations at the three sites. Sandra Hannum completed Figure 1, and Lance Trask completed Figures 2-8 for this article. Lastly, we thank the landowner, Lonnie Lindsey, for permission to work at these three sites, and for his support of the remote sensing work.

\section{References Cited}

Perttula, T. K.

2011 The Ceramic Artifacts from the Lang Pasture Site (41AN38) and the Place of the Site within an Upper Neches River Basin Caddo Ceramic Tradition. In Archeological Investigations at the Lang Pasture Site (41AN38) in the Upper Neches River Basin of East Texas, assembled and edited by T. K. Perttula, D. B. Kelley, and R. A. Ricklis, pp. 145-320. Archeological Studies Program Report No. 129, Texas Department of Transportation, Environmental Affairs Division, Austin.

Perttula, T. K. and K. Stingley

2016a Additional Material Culture Remains from the Bowles Creek Site (41CE475) in Cherokee County, Texas. Journal of Northeast Texas Archaeology 67:7-14.

2016b Analysis of the Recovered Artifacts from the Controlled Surface Collection at the Peach Orchard Site (41CE477), Cherokee County, Texas. Journal of Northeast Texas Archaeology 70:91-110.

Perttula, T. K., K. Stingley, and M. Walters

2016 Historic Caddo Archaeological Sites in Cherokee County, Texas. Journal of Northeast Texas Archaeology 65:1-24.

Reimer, P. J., E. Bard, A. Bayliss, J. W. Beck, P. G. Blackwell, C. Bronk Ramsey, C. E. Buck, H. Cheng, R. L. Edwards, M. Friedrich, P. M. Grootes, T. P. Guilderson, H. Haflidason, I. Hajdas, C. Hatte, T. J. Heaton, D. L. Hoffman, A. G. Hogg, K. A. Hughen, K. F. Kaiser, B. Kromer, S. W. Manning, M. Niu, R. W. Reimer, D. A. Richards, E. M. Scitt, J. R. Southon, R. A. Staff, C. S. M. Turney, and J. van der Plicht

2013 IntCal13 and Marine13 Radiocarbon Age Calibration Curves 0-50,000 Years Cal BP. Radiocarbon 55(4):1869-1887. 